\title{
The secret book trade after the outbreak of the Great French Revolution \\ Symptoms of the latent history of communication
}

\author{
IVONA K O L L Á R O V Á
}

\begin{abstract}
KOLLÁROVÁ, Ivona. The secret book trade after the outbreak of the Great French Revolution. Symptoms of the latent history of communication. Historický časopis, 2018, 66, 5, pp. 815-848, Bratislava.

The study analyses the censorship legislation and censorship records from the period of the Great French Revolution with the aim of pointing to the existence of a latent world in the history of communications as a result of the action of disciplinizing pressure. It captures the investigation of the distribution of anonymous political pamphlets and the unsuccessful search of the whole of Hungary for the secret private printing press with the aim of eliminating the problematic anonymous texts that threatened the public peace. Analysis of the innovative censorship legislation and sources on the investigation and testimony of importers enable us to generalize about not only the adaptation of importing practices to the adjusted conditions, but also about the methods of exculpation in the detention of suspected goods. The study shows that the illegal book trade was an important part of the history of communications, which spread and reproduced untolerated ideas in spite of prohibitions.

Key words: Great French Revolution. Publishing of books. Book trade, Censorship. Disciplinization. Latence. 18th century. Kingdom of Hungary. DOI: https://doi.org/10.31577/histcaso.2018.66.5.2
\end{abstract}

"When I want, for example in Bratislava, to get such a [forbidden - I. K.] book or several of them, I write on a small piece of paper: Gazette noire is wanted by Johann Friedel. This paper is sent to a book seller in Vienna at a cost of four kreuzers. The reply to the order also costs four kreuzers. I must sacrifice eight days and eight kreuzers, then the book will come to me."

Thus the Josephine writer Johann Friedel recorded that he obtained forbidden books in Bratislava by this unproblematic method. His statement underlines that what we can research and prove on the basis of sources is only the tip of the ice-

1 FRIEDEL, Johann. Briefe aus Wien verschiedenen Inhalts an einen Freund in Berlin. 2. Theil. Leipzig und Wien, 1785, p. 247-248. 
berg in the history of typographic culture. Disciplinary pressures created a latent world hidden from watching eyes. It is demanding to almost impossible to learn about this world by the usual methods. ${ }^{2}$ The sources only rarely offer mentions and indications. They show that a world that is not visible at first sight even in the censorship records actually existed. It had its procedures, routes and customers.

Controls and prohibitions are regarded today as part of the history of media communication and agreement also prevails that they did not prevent the circulation of non-conformist content, but caused the creation of communication channels hidden from the eye of the supervisor or operating invisibly. This approach changes the history of the book trade and reading into an attempt to reconstruct its hitherto imperfectly known other side.

The first steps beyond the limits of the classic interpretation of the history of the book trade have been taken. For example, the extensive surviving archive of the printing company Société Typographique de Neuchâtel, one of the largest producers and distributors of prohibited literature and pirate editions, has provoked research into illegal practices and new approaches to the history of the spreading of problematic content. Among other things, the archive of the Société reveals customers from the Kingdom of Hungary. ${ }^{3}$ It shows that the space production-distribution - reception is a latent space requiring research and effort to understand the mechanisms for preserving and spreading prohibited content in the historico - sociological framework of cultural evolution. ${ }^{4}$

2 On the model of social discipline: ČIČAJ, Viliam. Disciplinizácia ako historický fenomén. (Discipline as a historical phenomenon). In ČIČAJ, Viliam a kol. Sociálna disciplinizácia a zrod modernej spoločnosti. Bratislava: Historický ústav SAV, 2013, p. 9-24. ISBN 9788097064846. The term communication is used in this study in the narrow definition of media - typographic - communication. For a wider view: ČIČAJ, Viliam. Formálna a obsahová premena komunikačnej praxe v novoveku. (Formal and content change in communication practice in modern times.). In Historické štúdie 49, 2015, p. 9-18. ISBN 9788022414579. HAUG, Christine. Literatur aus dem Giftschrank - Kontexte und Mythen. Buchmarkt und zensurpolitische Strategien im literarischen Untergrund im Zeitalter der Aufklärung. Ein Forschungsbericht. In Archiv für Geschichte des Buchwesens 71, 2017, s. 185-226. ISSN 2006637.

3 Accessible on the internet: <http://fbtee.uws.edu.au/stn/interface/>. DARNTON, Robert. Literaten im Untergrund. Lesen, Schreiben und Publizieren im vorrevoluzionären Frankreich. Frankfurt am Main: Fischer-Taschenbuch-Verlag, 1988; GRANASZTÓI, Olga. Franciai könyvek Magyar olvasói: A tiltott irodalom fogadtatása Magyarországon 1770-1810. (French books, Hungarian readers: The reception of banned literature in Hungary, 1770 1810). Budapest: Universitas kiadó, 2009. ISBN 9789632005706; KRIŽANOVÁ, Petronela. Anton Löwe (1770 - 1799?) Príbeh zabudnutého kníhkupectva. (The story of a forgotten bookseller”). Bratislava : Detail, 2018, s. 86-88. ISBN 9788097251925.

4 I use the term "cultural evolution" in the sense of development or change, not of progress. I start from the socio-biological and historical-anthropological understanding of the term ac- 


\section{"Secret printing presses"}

The form of title page usual today did not originate from the need for public presentation of the author and publisher, but as a result of pressure from censorship in the 16th century. The effort of authors and publishers to be anonymous is provable over the next four centuries. The reason was not only problematic content, but also reprinting. Thanks to this pressure, the period from the 16th to first half of the 18th centuries is also the period of "secret", "moving" printing presses or the period when secret production pushed into territories with less threat of persecution, secretly imported and illegally distributed with possible disciplinary consequences after betrayal.

Josephinism brought to the book market more liberal conditions, the development of publishing activity and a conspicuous increase in the number of new printing businesses. The increased anonymity was interpreted by the opponents of liberalization as penalty free spreading of any content with harmful effects on the ever increasing number of recipients. ${ }^{5}$ Some pointed out that the printers had a sort of system for warning about and hiding problematic books. ${ }^{6}$

The Great French Revolution again stimulated pressures for control. In conservative circles there were fears that the spread of reading would spread the danger of decline of the political and moral system, that the ideas of equality and social mobility were spreading dangerously and threatening the "public peace". This atmosphere narrowed the space for permitted content and reshaped censorship into a new form.

Various texts with political content appeared in 1791-1792 in connection with preparations for a session of the Hungarian Parliament and the current political situation. Among other things, Jozef Hajnóczy wrote and published the Dissertatio Politico-Publica de Regiae Potestatis in Hungaria Limitibus. At the same time, again without publication data, he published De comitiis regni Hungariae, deque Organisatione eorundem Dissertatio Iuris publici Hungarici. In 1792, Hajnóczy's treatises De diversis subsidiis dissertatio and Oratio pro Leopoldo II by Ignaz Joseph Martinovics were published with the imprint "Germania". A common feature of all these texts was anonymity with absent, incomplete or fictitious publication data. The works appeared in unknown approbation circumstances. They were progressively banned in 1792 and investigations were

cepted in the humanities.

5 KOLLÁROVÁ, Ivona. Slobodný vydavatel', mysliaci čitatel'. (Free publisher, thinking reader). Budmerice: Vydavatel'stvo Rak, 2013, p. 170-174. ISBN 9788085501575.

6 Magyar Nemzeti Levéltár - Országos Levéltár (hereinafter MNL - OL), C 60, cs. 71, 53960, f. 509-510. An anonymous call for the authorities to search Weber's printing business and question his employees without them being warned in advance. 
launched. Retrospective bans were nothing new, but the method used to prevent the distribution of text was novel. ${ }^{7}$

Before 1792 sporadic reports appeared of investigations or declarations from the censor provoked a prohibition and local investigation. This changed fundamentally in 1792. This system cannot be compared with anything in the history of censorship in Hungary. The prohibition of a publication was followed by investigations with the participation of all components available to the censors. The pamphlet Oratio ad proceres can serve as an example. It appeared in 1790 with the false imprint "Parisinis". It was banned only in April 1792, that is shortly before the accession of Francis II to the throne. On the basis of this ban, which described the text as harmful to the public good, the governor's office instructed the town and county authorities and all local censors through directors of school districts that they had to find out whether any printers or sellers of books have this text, confiscate any copies they find and investigate the name of the author and printer. They have to prevent the printing and distribution of similar texts, but how to do this is not specified. ${ }^{8}$ Reports from all the towns and counties in the kingdom on the results of these measures gradually began to reach the governor's office. The town and county authorities secured investigation in their "districts" and wrote reports on whether they had found the banned texts and how many copies. This produced a hitherto unprecedented quantity of correspondence about a brochure with only a few pages. However, the result was not remarkable. It was exceptional for anything to have been discovered or any copies found. This also happened in the case of Oratio ad proceres. In May 1792, the Bratislava city authorities declared that nothing had been found and submitted a report on the investigation by the city captain Ján Gašpar Púchovský, according to which the publishers, book shops, owner of the reading room and book binder knew nothing about the pamphlet, nobody had heard of it, they did not know the name of the author or where it was printed. One bookseller and printer Anton Löwe admitted that somebody had asked about the publication and wanted to buy it. ${ }^{9}$ Similar reports came from the other towns and counties. However, by this time a Hungarian translation of the pamphlet was already spreading. In May 1792 the Chancellary of Hungary issued a new order - to seek the author of the pamphlet especially in Hungary, to seek the author of the translation and

7 The political background to the publication of treatises: WANGERMANN, Ernst. Von Joseph II. zu den Jakobiner-Prozessen. Wien etc.: Europa Verlag, 1966, p. 84, 100-102; KOWALSKÁ, Eva - KANTEK, Karol. Uhorská rapsódia alebo tragický pribeh osvietenca Jozefa Hajnóczyho. (Hungarian rhapsody or the tragic story of the enlightenment intellectual Jozef Hajnóczy). Bratislava: Veda, 2008. ISBN 9788022410342.

8 Prohibition and order to investigate: MNL-OL, C 60, cs. 79, 8915, f. 373-377 .

$9 \mathrm{MNL}-\mathrm{OL}, \mathrm{C} 60$, cs. 79, 12004, 411-413. 
to confiscate also the Hungarian version. The town authorities of Pécs reported the confiscation of 21 copies of Oratio ad Proceres. A local bookseller testified that a soldier had left one copy to be bound. He did not know, but he thought that the books were printed in Bratislava. ${ }^{10}$ At this time, they were already seeking not only the above mentioned two pamphlets including one translation, but also another pamphlet by Martinovics Oratio pro Leopoldo II. Púchovský's April declaration shows that the reading room owner Johann Gottfried Weissenthall and the booksellers Andreas Schwaiger, Filip Ulrich Mahler and Johann Doll admitted to selling a few copies. They all stated that they obtained copies from Anton Löwe, who admitted to having 100 copies from which 52 were found. He declared that he had obtained them from the Viennese printer Johann Martin Weimar, who had allegedly acquired the imprimatur for the printing. A copy of this authorization is included in the file. Nobody stated the name of the author.

In August the Bratislava city captain Púchovský carried out another investigation and found some copies of Oratio pro Leopoldo II in Löwe's possession. He again stated that he had obtained them from Weimar. The bookseller Schwaiger stated that he had had some copies from the Viennese bookseller Christoph Petr Rehm, but had sold them all to unknown customers. ${ }^{11}$ A Trnava bookseller told investigators that he had heard that the book was printed in Bratislava. ${ }^{12}$

The stream of negative reports is sometimes interrupted by the confiscation of copies, or at least an admission by a bookseller that somebody wanted the pamphlet. The Pest city councillors were successful in the case of the booksellers Kilian and Stahel. In Komárno pamphlets were found in the possession of the ex-captain Johann Laczkovics (1754-1795). A person entrusted with distribution betrayed him. ${ }^{13}$ In this case the investigation led to ascertaining the name of the author or translator. Suspicion fell on Laczkovics and he confessed. According to him it was an approved work also known beyond the borders of Hungary. It contained nothing that could be considered rebellious, there were no "gallica

10 The Hungarian version: [MARTINOVICS, Ignaz Joseph]. A Magyar-ország gyülésiben egyben-gyült méltgs és tekintetes nemes rendekhez 1790. esztendöben tartattatott beszéd. (Speech to the Hungarian nobility in parliament in 1790). [translated J. Laczkovics]. [s. 1.]: [s. t.], 1791. Investigation: MNL - OL, C 60, cs. 79, 16516, f. 456. [HOFFMANN, Leopold Alois]. Grosse Wahrheiten und Beweise in einem kleinen Auszuge aus der ungarischen Geschichte. Frankfurt und Leipzig [Wien]: [Weimar und Schladebach], 1792. MNL - OL, C 60, cs. 13709, f. 435. Prohibition and order to confiscate, punish the author and prevent the publication of a second part: MNL - OL, C 60, cs. 80, 13291, f. 85.

11 MNL-OL, C 60, cs. 80, 8630, f. 296-299; cs. 79, 17796, f. 480-482. Further reports on confiscation: 23150, f. 652. Further indications leading to Rehm: cs. 80, 10453, f. 325.

12 MNL-OL, C 60, cs. 80, 9294, f. 309.

13 MNL - OL, C 60, cs. 79, 19264, f. 52, cs. 82. Three copies were also found in Buda: cs. 79, 20158. f. $549 ; 23575$, f. $658-661$. Further reports of confiscations in cs. $80-82$. 
principia”, and it was entirely in harmony with the policy followed by Maria Theresa, Joseph II and Leopold II. Allegedly, it was all only a conspiracy against his person. ${ }^{14}$ The governor's office set the punishment for Laczkovics - he had to get a reprimand from the Pest city authorities. However, the investigation had to continue with the aim of finding out where the texts were printed..$^{15}$

A secret or fictitious place of publication was one of the important preventive measures of authors and publishers. It aimed to secure anonymity and so also impunity. Although false imprints are more or less as old as printing, their purpose changed over the centuries, or the proportions of the reasons for concealment changed. Only some of the incomplete or fictitious imprints are connected with the need to conceal the identity of somebody who could be punished for spreading dangerous content. A substantial part of false imprints are connected with illegal reprinting. We also find here something that could be tentatively interpreted as a change of "climate" in the period of the Great French Revolution. In the bibliography covering production of books and pamphlets from Hungary with false imprints, we can see precisely these changes in the purpose of their use. The catalogue identifies 33 publications with false imprints from the period 1781-1790, namely the period of the Josephine free press. Ten of these date from only one year, 1790 and were published in connection with the Parliament of Hungary and topical socio-political questions. This trend continued in the following years. In the period 1791-1800, the bibliography identifies 23 publications with fictitious imprints, among which a substantial proportion have a political orientation, including criticism of the Roman Catholic Church. In the previous period, it had taken more than 30 years to produce such a large quantity - more than 50 publications with false imprints, and the reasons were much more non-political - they were mostly unauthorized reprints. If we return to the 1790 s, we must again admit that this is only a fragment of reality. A substantial proportion of these publications are preserved in only one or two copies, and there are probably many still to be discovered or not preserved at all. ${ }^{16}$ They include Martinovics's treatises. Landerer's printing company was one of the greatest producers of false or concealed imprints. It cooperated with Friedrich von Trenck, Johann Laczkovics, Johann Molnár and other "problematic" authors of this period. Part of the output of Landerer's widely known, prospering printing company was under the shadow of illegality. This was partly a result of the

14 MNL-OL, cs. 82, 2784, f. 52 - 53, 2248, f. 54.

15 MNL - OL, cs. 82, 2784, f. 56-57. Further investigation: cs. 82, 12889, f. 150-154; cs. 82, 16572; f. 196-198; cs. 82, 19161, f. 264-266.

16 VIZKELETY-ECSEDY, Judit. Titkos nyomdahelyü régi magyar könyvek 1539-1800. (Old Hungarian books with secret imprints). Budapest: Borda Antikvárium, 1996, p. 91-156. 
later proved Jacobin inclinations of Michal Landerer, a printer in Pest and son of Ján Michal Landerer, owner of printing houses in Bratislava and Košice.

The media environment full of unpunished anonymity provoked many legislative changes. One of them was a decree from 9 October 1792, according to which all town and county authorities had to produce lists of printers, booksellers and bookbinders in their districts. ${ }^{17}$ In the following period, as in the case of the investigation of the banned pamphlets, lists of printers, booksellers and bookbinders arrived from all corners of the Kingdom of Hungary. If a county or town did not have any in its territory, it was also obliged to report this fact. ${ }^{18}$

A further decree was issued on 14 January 1793. It appealed to the public good and public peace threatened by subversive books from private printing presses or unauthorized printers, which avoided censorship. Such private printing presses belonged under royal jurisdiction, and after publication of the mandate they all had to be closed down. Those which did not obey and those who traded in books coming from these printing presses or distributed them for free, had to be dealt with according to article 45 from 1599, according to which printing of "old" no longer permitted calendars was prohibited and punishable by a fine of 1000 gulden. Printers of subversive books were threatened with judicial proceedings and town authorities could order the closure of printing businesses. The decree also ordered a reward of 200 gulden for people, who helped to uncover such private printing businesses. The decree also prohibited the unauthorized production of letters and especially their sale to unauthorized printing businesses. The governor's office had to secure the distribution of the decree across the kingdom, and ensure that all printing businesses prove that they were authorized, send information about the books they published without censorship and verify the existence of private printing businesses. The term "privata" printing business appears here for the first time in legislation from Hungary with the aim of distinguishing authorized printing businesses from those operating without authorization and uncovering the hypothetical source of illegal publications. ${ }^{19}$

On the basis of this decree, the governor's office had to create a circular for all the towns and counties. It originated in June 1793 and the adjectives "domestica" and "secreta" were added to "private". The secret aspect was emphasized, meaning not only unauthorized, but also concealed and presumably with illegal intensions. ${ }^{20}$

17 MNL-OL, C 60, cs. 208, 5450/12053, f. 232.

$18 \mathrm{MNL}-\mathrm{OL}, \mathrm{C} 60$, cs. 208, 22615, 9. 10. 1792. Declarations in cs. 82-83.

19 MNL-OL, C 60, cs. 208, 2859/266, f. 206, 5. 2. 1793, f. 206.

20 MNL - OL, C 60, cs. 208, 16039, f. 235-238. The dispute over responsibilities analysed in the following study arose at this time: KOLLÁROVÁ, Ivona. Sloboda tlače v uhorskom neskoroosvietenskom diskurze. (Freedom of the press in Late Enlightenment discourse in 
Several months of investigation began on the state of book printing in the Kingdom of Hungary. At this time, the governor's office still did not have a list of the printers in all the towns and counties as was required by the decree from October 1792. The first reports on book printers and their authorizations began to arrive in July 1793. The other towns and counties proceeded similarly. They identified the printers in the territory of a town and confirmed their authorizations. If no printer of books operated in their territory, they reported that no "secreta" or "publica typographia" operated. No town or county authority reported that they knew of an illegal printer or who illegally produced and traded in fount or the products of an illegal printer. Sometimes they found that a printer really did not have a valid authorization, but he could prove who he had bought his printing press from. The town authorities supported him as a legal printer, who fulfilled his duties and served the town community and administration. ${ }^{21}$

The counties and towns also had to investigate the production and sale of letters for printing presses. The decree did not bring any results here either. They found that the only person who cast letters at this time was Ján Michal Landerer, but this was more or less well known. ${ }^{22}$ Secret production by him or any other producer was not proved, and neither was sale to an illegal hitherto unknown business. The circular also directly encouraged people with the offer of a reward of 200 gulden for passing on any information about illegal typographic activities and the sale of its products. However, this motivation did not lead to the uncovering of any illegal activities. We also do not know how the county and town authorities undertook the investigation or what effort they made to uncover any secret printers.

In this context, the question arises of how did the phenomenon of the secret illegal printing operation arise or revive after being absent from this region since the Counter Reformation. There could be indications, traces and concrete statements in its background. "Printers are secretly printing subversive books" is a phrase in many decrees of this period. However, it says nothing about illegal printing operations directed exclusively to political output in the true sense of the word. They succeeded in discovering an unauthorized typographic unit only

Hungary). In Historický časopis, 2015, year 63, no. 3, p. 405-426.

The governor's office strove to delay the preparation of the circular apparently because of the discussions in parliament and preparation of legislation on freedom of the press. The Chancellary of Hungary reacted to this. Text of the circular: MV SR, Štátny archív v Bratislave (hereinafter ŠABA): Kongregačné písomnosti (Congregation documents), 1793, f. 6, no. 45.

21 KOLLÁROVÁ, Ivona. Tajná tlačiareň a ohrozovane verejného pokoja po Vel'kej francúzskej revolúcii. (The secret printing press and threats to public order after the Great French Revolution). In Kniha 2017: Zborník o problémoch a dejinách knižnej kultúry. Martin: Slovenská národná knižnica, 2017, p. 207-208.

22 MNL-OL. C 60, cs. 82, 29326, f. 505-512. 
in 1798. Investigation showed that it belonged to the Franciscan Raphael Takáts, and starting in 1790 he moved it around the country from Vác to Subotica. He printed small religious works and a dictionary using a false imprint. The fined printing press of the Franciscan friar was not what the authorities were looking for. No production threatening the public peace could be proved. However, investigation proved that obtaining and operating a "hand press" was not a paranoid construct but a reality. A printing press had operated for eight years without anybody reporting its owner, in spite of a decree promising a financial reward for such reports, in spite of the fact that people cooperating with him transported it from place to place, provided the necessary materials and received its products, which must have numbered dozens to hundreds. ${ }^{23}$

Investigation of the secret press also brought an unwanted effect. The information about printing presses and their authorization began to be accompanied by "representations" from the counties that the activity of printing presses did not come under royal jurisdiction.

This began a dispute about responsibilities. From July 1793 to March 1794 at least 17 counties of Hungary produced statements casting doubt on the decrees. They included the counties of Abov, Gemer, Hont, Nitra, Zvolen, Novohrad, Zemplín, Spiš and later others. The essence of this dispute was interpretation of the legislative article from 1599. The counties pointed to its inappropriate application and misinterpretation. According to them, the legislation contained no mention of a private person being forbidden to own a printing press without authorization. According to the argumentation of the counties, such a ban could arise only from agreement between the king and the estates, it was not subject to the royal prerogative. The king could ask the estates to set a general boundary for the freedom of the press. The estates are the body responsible for freedom of the press. At the same time, there was no act enabling the conviction and punishment of a member of the noble estate for owning a private printing press, or for printing, buying or selling forbidden books. This dispute was carried on in the spirit of Enlightenment ideas, in the context of the reform parliament of 1790-1791, and preparation of a new constitution with the liberal content we find in it. It is necessary to see it in the context of Hungarian constitutionalism and its development. ${ }^{24}$

The declarations of the counties that there was no legislation allowing the punishment of a member of the nobility for possession of a printing press or for printing and selling unauthorized texts creates space for consideration of whether there was organized opposition to the circular in the reformist oriented

23 KOLLÁROVÁ, ref. 21, p. 209-210.

24 KOLLÁROVÁ, ref. 20, p. 415-421. Several similar statements by other Hungarian counties appeared in the years 1794-1795. 
circles of the Hungarian nobility, but we have to admit that the existence of such a printing press is unconfirmed.

\section{Legislative pressure}

The Josephine period was characterized by relative freedom of the book trade. However, at the beginning of the 1790s a change in the social climate began to be expressed in changed rules for the importing and sale of books in a large part of Europe. ${ }^{25}$

The first decree of the Emperor Leopold II came in September 1790. At first sight it represented continuity with the Josephine system. Censors had to follow the instructions from 1782 until a new act was passed and take care that defamatory and subversive books were not distributed in the country. The decree emphasized that everything that threatened the maintenance of general peace or promoted errors, divisions and the disobedience of citizens towards the monarch, books encouraging religious indifference or insulting the clergy must be considered prohibited. The instruction speaks not only of "books", but also of "libel$l i$ ", meaning mainly brochures and pamphlets. ${ }^{26}$ Reaction to the anti-Catholic atmosphere of the previous decade and fear of revolution are visible especially in the emphasis on maintenance of public peace. This was only the beginning. A year later, an instruction was issued on revision of the books allowed during the reign of Joseph II. Special rules were created for the censorship of Hungarian language newspapers. The censors had to make sure that information about revolution did not appear in them. ${ }^{27}$

Declaration 8948 became valid in April 1792. It set the responsibilities of individual inspectors and their superiors starting from the system created in the 1780s. Local inspectors were professors in academies and head masters of grammar schools. Books imported through Vienna or other points had to be stopped at the Hungarian customs posts and checked by local inspectors. Permitted publications had to be released to their owners, while forbidden items had to be sent back to whoever had sent them. Booksellers could gain permission from censors already in Vienna and so gain approval from the Hungarian authorities. Books with limited (transeat) approval could not reach the eyes of the public in reading

25 HAEFS, Wilhelm. Zensur und Bücherpolizei: Zur Kommunikationskontrolle im Alten Reich und in Frankreich im 18. Jahrhundert. In HAUG, Christine - MAYER, Franziska SCHRÖDER, Winfried (eds.). Geheimliteratur und Geheimbuchhandel in Europa im 18. Jahrhundert. Wiesbaden: Harrassowitz, 2011, p. 52-53. ISBN 9783447064781.

26 MNL - OL, C 60, cs. 208, 25387, f. 153, 13 Sept 1790.

27 MNL-OL, C 60, cs. 208, 16566, 6 Sept 1791. 
rooms or sale catalogues. Every bookseller's advertisement in a newspaper had to undergo censorship before publication. ${ }^{28}$

In connection with these decrees, the Royal Chancellary of Hungary produced a list of Hungarian inspection points for German and French customs posts, so that they would know where packages had to be directed before they reached their final destinations. ${ }^{29}$

In August 1792 a decree was issued stating the need to prevent booksellers in Hungary importing books "indirecta via" and "per praevaricationem". It was probably a reflection of the spread of unwanted books in the country. On the basis of this decree, all booksellers in the kingdom were obliged to submit lists of the books they had for sale to the inspectors. The inspectors also had to consider the places where markets were held and booksellers sometimes offered their books. The aim of these lists was to separate permitted books from prohibited and force booksellers to send the prohibited books out of the kingdom at their own expense. When inspecting catalogues, local inspectors also had the right to find out where forbidden books came from, how many a bookseller had imported, and whether he had bought them before or after publication of the ban. ${ }^{30}$

These decrees probably did not have the expected effect. Declaration 4056 became effective in April 1793. It defined the duties of printers, booksellers and everybody trading in books, as well as measures for supervising inspectors. The aim was, as was repeated in all the declarations from this period, "to effectively and by all methods prevent the distribution of subversive books so that peace and the public good are maintained". Apart from the duty to compile catalogues of all books sold and make them available to the inspectors for comparison with the catalogues of censored and banned books, the booksellers also had the right to receive information about the content of these catalogues, which were updated every 15 days. In the case of an offence they could not appeal to not knowing that a book was banned. If a bookseller wanted to sell a book that was not in

28 MNL - OL, C 60, cs 208, 8948, f. 177-178, 179-180; ŠABA, Kongregačné písomnosti, 1792, f. 4, N. 50.

29 MNL-OL, C 60, cs. 208, 10826, f. 185-189.

30 MNL - OL, C 60, cs. 208, 20151, f. 195-196; 27811, f. 203-204. The rule about sending forbidden books back to the suppliers was problematic. In March 1795, the Bratislava study director informed the governor's office that the Bratislava booksellers Mahler, Löwe, Schwaiger and Doll refused to send about 300 detained books back to their commission-agent in Leipzig. They did this on the basis of a joint declaration, according to which the booksellers have an oral agreement that the books ordered from the commission-agent will not be sent back, and the fact that they have been banned by the time of sale is their own risk. MNL - OL, C 60 , cs. 89, 5483, f. 103-108; the Chancellary of Hungary insisted that the books be sent back. MNL - OL, C 60, cs. 89, 8539, f. 131. 
the catalogue of censored books, he had to get permission from the inspector and if necessary prove this permission. For this purpose it was necessary to update and prepare the necessary number of copies of the catalogues for individual inspectors. In the case of an offence, namely the sale of banned or uncensored books, the seller had to be punished by confiscation, as determined by town authorities, "because by means of selling such books he give opportunities for the evil that comes from their distribution". However, this had to happen only on a first offence. In the event of a second offence, he was threatened with loss of his gild authorization, which meant a ban on continued activity and a punishment resulting from an offence against a royal decree and against the public good and order. The punishment of cancellation of authorization also threatened those who printed publications without preventive censorship.

These decrees concerned printers of books, booksellers, bookbinders and all who traded in books. However, it was also necessary to monitor persons importing books for their own use. In relation to this situation, it is necessary to comment that Joseph II had distanced himself from such controls as a humiliating procedure. The situation changed. Books of foreigners coming into the country had to be deposited and returned when they left. Private persons importing books could not cross the frontier without checks. It was still true that educated people from certain classes could import banned books for their own use, but it was already necessary to obtain permission from the governor's office on the basis of an assessment from a censor. If the governor's office gave permission, the person with the authorization had to sign a declaration that the book would not be accessible to anybody else and he had only one copy of each title. Apart from this, the inspectors had to report every three months on what books had been imported and by who. The customs posts could not release books to their owners except on the basis of such an authorization, and an inspector was obliged to verify whether the package really contained only what was specified in the authorization and whether there was really only one copy. If this condition was not fulfilled, the inspector had the right to confiscate everything not mentioned in the authorization. The post offices also had to be informed about this decree, so that they would not hand over anything that had not been examined by a censor.

The declaration determined the responsibilities of the inspectors and of the governor's office. The Chancellery of Hungary had to report the localities where booksellers operated but there were no inspectors, and propose measures either to appoint further local inspectors, add the localities to the responsibilities of neighbouring inspectors or find other satisfactory ways of covering uncovered territories. ${ }^{31}$ The governor's office observed that the decrees were beginning to

31 MNL - OL, C 60, cs. 208, 12503 f. 216-219. This declaration in the form of instructions for censors and booksellers: cs. 208, 28068, f. 292-296, to study directors, the Buda inspector 
be incompatible and unimplementable. This applied especially to the provisions concerning supervision of imports by private persons. Among other things, it was thought that the responsibility for granting private persons permission to import books had to remain with the local inspectors and should not be transferred to the governor's office. They observed that preparation of reports about what banned books could be brought into the kingdom and to whom would to too demanding and would not fulfil its aim. There were a great many books in the kingdom for which no authorization had been issued. The governor's office also held the view that the number of local inspectors - teachers at academies or head masters of larger or smaller grammar schools - was adequate in relation to the number of printing businesses and booksellers, so it was not necessary to appoint more. They also stated that the declaration contained much repetition of other valid decrees and so did not need to be published. ${ }^{32}$

In the end, the governor's office prepared a proposed edict repeating many points from the preceding decrees. ${ }^{33}$ The new features include the directing of some parts towards the post office and post wagons. The declaration referred to a decree from 1792 that books delivered by post wagons should not be handed over to their owners except on the basis of written permission, which the owner could get only on the basis of inspection of parcels by the inspection service to find out whether they really contained the books for which permission had been issued and in no more than one copy. The post offices had to be instructed that they should hand over no books except on the basis of permission. All had to be submitted for inspection by the customs posts and inspectors. ${ }^{34}$ This decree appeared in April 1793 and a special decree for post wagons was issued in connection with it. The decree prescribed searches of post wagons and regulated the approach of the inspector to dealing with packages containing books, so that banned books did not get into the kingdom. ${ }^{35}$ The postal service did not appear in censorship legislation before 1790 , probably mainly because booksellers made minimal use of it. It mainly provided individual delivery of periodicals.

This legislative pressure resulted in more obligations for the inspectors. Apart from those working in the main centres, the records include reports from local

and the Pest local inspector: f. 286-291, postal prefecture: f. 285. The decree on the taking of books from foreigners appeared in February 1793: cs. 208. 5458.

$32 \mathrm{MNL}-\mathrm{OL}, \mathrm{C} 60,5450 / 12053$, f. 224-230. Declaration aimed at banning secret printing operations.

33 Proposed edict (intimatum) of the governor's office compiled on the basis of this declaration: MNL - OL, cs. 208, 10811 A. 3245. 794., f. 317-318, B. 3248 f.319-22.

34 MNL-OL, C 60, cs. 208, 12503, f. 216-219.

35 MNL - OL, C 60, cs. 208, 14897, f. 233, 6. 5. 1793; instruction for censors and booksellers: 28068, f. 292-296; instruction for post prefectures: f. 285. 
inspectors in the smaller towns, where they had been rather exceptional in the 1780s. The increased duties of censors in the typographic and bookselling centres and near customs posts were probably considerable. This is also shown by a letter from a Bratislava local inspector Karol Hadaly. In his request for increased pay, he describes his duties. He was responsible for three reading rooms, four printing businesses, regular bookshops and the so-called frontier store. He explained that although booksellers could choose between inspection in Vienna and Bratislava, they chose Bratislava mainly because of less effort and expense. Books often had to be stored because he still did not have the current catalogue of censored books, which was updated every 15 days. There were usually 50-100 books. In connection with this, he had the duty and work requiring considerable time of keeping records and communicating with owners and with his superiors.

Apart from the regular booksellers who supplied "half of Hungary" with books, there were a multitude of bookbinders and other tradesmen concerned with the importing of books, which all had to pass through the Bratislava customs post and be inspected. The inspection of books transported by travellers must also be included in his duties. Hadaly states that he rarely had a day without an inspection case, and often six or seven such cases were proceeding on the same day. ${ }^{36}$

Hadaly's letter speaks of how legislative pressure hand in hand with a growing book trade greatly increased his burden as a censor. It says nothing about whether the greater quantity of work required by bureaucratic control procedures really worked as a more effective filter of the spread of unwanted ideas. The inspection of post wagons shows that this method of transport hitherto un-noticed by the censors was affected by fear of the spread of subversive books. The relatively free importing of books by private persons was replaced by a demanding authorization procedure by the governor's council. These and similar decrees probably reacted to specific cases of the private importing of unwanted books and periodicals. They may have reacted to denunciations and complaints, which were not so rare in this period, and the investigations that were sometimes launched usually with almost no results.

Michael Wögebauer has pointed out that at the end of the 18th century, censorship and numerous prohibitions created conflict in the system. The book trade was not only a system for securing the supply of certain goods, but also an economic system supporting an ever more numerous group of people - booksellers, deliverers and increasingly professional writers. This also made it impossible to

36 MNL-OL, C 60, cs. 88, 3891, f. 23-24. Hadaly's statements are not entirely in harmony with the testimony of the booksellers that they preferred censorship in Vienna. In September books imported to Hungary through Vienna were sent for censorship by the clerk (concipiens), and censor Karol Escherics: cs. 85, 24765, f. 564-566. 
entirely stop the flow of unwanted texts. It adapted to the conditions and functioned in an "invisible" system. ${ }^{37}$

\section{Booksellers and clandestine circulation}

In 1790 the Berlinischen Monathschrift published articles by the theorist of state law Karl Clauer demanding universal acceptance of the Declaration of the Rights of Man. Clauer left Berlin in 1791 and moved to Strasbourg, where he wrote two anonymous leaflets warning about war against revolutionary France and appealing to the people of the German states to rise up against their own despots. The first leaflet Kreuzzug gegen die Franken appeared on 18 June 1791. It was reprinted many times and translated into various languages. ${ }^{38}$

The German version of the leaflet was banned in the Habsburg Monarchy in autumn 1791..$^{39}$ Investigation of the Hungarian Jacobins proves that the leaflet was probably well-known in the Monarchy, and was distributed in spite of the ban. There were numerous investigations and confiscations. However, its anonymous author was less well known. In his reports to the chief of the secret police Franz Gotthardi Ignaz Joseph Martinovics stated among other things that he had seen the leaflet. ${ }^{40}$ However, he gave inaccurate information about its author. Ferdinand Prince of Brunswick allegedly gave a thousand gulden to Johann Heinrich Campe, another admirer of the revolution, for writing the Kreuzzug. We do not know whether Martinovics deliberately deceived Gotthardi or really thought the pamphlet was written by the problematic publicist Campe. ${ }^{41}$

In November 1791 the Chancellery of Hungary ordered searches of bookshops with the aim of finding and confiscating banned books and any copies of the pamphlet. ${ }^{42}$ The investigation brought results. The Kreuzzug was found in several bookshops in Bratislava and Pest. The Chancellery of Hungary instructed the governor's office on how to proceed. All the Budapest booksellers had to be

37 WÖGERBAUER, Michael. Geheime Wege nach Leipzig? Die Entstehung der Berufsschriftstellerei in den Böhmischen Ländern und die österreichische Zensur. In HAUG, Christine MAYER, Franziska - SCHRÖDER, Winfried (eds.). Geheimliteratur und Geheimbuchhandel in Europa im 18. Jahrhundert. Wiesbaden: Harrassowitz, 2011, p. 187. ISBN 9783447064781. GRAB, Walter. Revolutionsfreunde in Preussen im Zeitalter der Französichen Revolution. In BÜSCH, Otto - NEUGEBAUER-WÖLK, Monike (eds.). Preussen und die Revolutionäre Herausforderungen seit 1789. Berlin; New York: Walter de Gruyter, 1991, p. 119-144, here p. 120. ISBN 9783110126846. Grab mentions a translation into Hungarian, but this translation or its publication cannot be proved in the literature and sources.

$39 \mathrm{MNL}-\mathrm{OL}$, cs. 78, 6908, f. 362-363.

40 BENDA, Kálmán. A magyar jakobinusok iratai. I. (Documents of the Hungarian Jacobins). Budapest: Akadémiai kiadó, 1957, p. 492-493; KOWALSKÁ - KANTEK, ref. 7, p. 143.

41 BENDA, ref. 40, p. 662-664, 783-784.

42 MNL-OL, C 60, cs. 208, 27811, f. 199-201. 
investigated at the same time so that one bookseller could not store problematic books with another bookseller. The investigation also had to find out whether a bookseller had a private printing press and how he obtained forbidden works. ${ }^{43}$ In July 1792, the Budapest bookseller Johann Lindauer had to testify. He stated that he had about 20 copies in the last year. He got them from his brother, a bookseller in Munich. To the question of whether he sent any of these copies to other booksellers, and if yes, to who and how many, he replied that he had sent 12 copies to Filip Ulrich Mahler in Bratislava and sold 8, but he did not say to who. To the question of whether he knew the content of the books, whether they were imported with the knowledge of the inspectors and if yes, which inspectorate had inspected them, he replied that he knew nothing about the content and the books were inspected in Vienna. Lindauer's testimony did not include the whole truth. It became clear that not only the above mentioned Mahler, but also other Bratislava booksellers - Anton Löwe and Andreas Schwaiger - had and sold copies. Officials in the County of Bratislava had to investigate this. ${ }^{44}$ Schwaiger testified that he had received 12 copies from Lindauer, the same number as Mahler, and all had been sold by the time they testified. However, this admission came only during the second investigation. During the first, Schwaiger was absent and his employee claimed to know nothing about the book. A similar scenario occurred at Löwe's bookshop. A servant was looking after the shop during his absence. The servant no longer worked there and Löwe allegedly had no exact information about whether he had sold the brochure or not. However, during his second testimony, he "remembered" that six months before Lindauer had sent 12 copies, which he immediately sold. He did not register the names of the buyers, but he had allegedly sold two or three copies to a certain officer. The deputy sheriff of Bratislava Michal Beňovský informed the governor's office about the investigation. Apart from the booksellers being questioned, their stores were searched, but apparently nothing was found.

However, the important thing was that they had proved that Lindauer had lied and all those questioned had been evasive in the first investigation. The testimonies of the booksellers were not compatible and showed that several times more copies had been sold in Budapest and Bratislava than Lindauer had admitted. The pamphlet probably sold well or the booksellers succeeded in hiding unsold

43 MNL - OL, C 60, cs. 78, 22262, f. 177-179. Problematic books were found especially in the Kilian and Stahel bookshop: cs. 79, 19264, f. 524. The pamphlet appears here as "Die Züge gegen die Franken " attributed to Friedrich von Trenck by the censor. The finds also include Martinovics's Oratio ad proceses and a less well known text about censorship. [MARTINOVICS, Ignaz Joseph]. Discussio oratoria in eos, qui in librorum censuram invehuntur. [s. 1.] : [s. t.] [s. a.].

44 MNL-OL, C 60, cs. 81, 25333, f. 181-186. 
copies from the officials. When they wanted to question Lindauer again, they found that he had gone to Timişoara, ${ }^{45}$ but perhaps only to gain time. In February 1793, when answering the question of whether he had sent 12 copies each to the booksellers Löwe and Schwaiger, he replied that according to the accounts of the bookshop he really had sent these booksellers 12 copies each, but it was before the ban on them was published. However, this did not free him from guilt. A censor had to retain a suspect book and discuss it with his superiors. To the question of whether he had sent copies to other booksellers, he replied that he knew nothing about this. To the question of how many copies he had, he replied that he had exchanged copies at the Easter Fair in Leipzig with his brother the Munich bookseller, in return for other books. Allegedly, he had not recorded the exact number of copies and this exchange was not recorded in his accounts. To the question of who had inspected them when they were imported, he repeated that the title had passed censorship in Vienna. Clearly, Lindauer had changed his testimony under pressure from circumstances and not only concerning the number of copies. The previously mentioned Mahler disappeared from the transaction. The governor's office ordered the Pest city authorities to investigate who had inspected the Kreuzzug. ${ }^{46}$ Lindauer sent a declaration that he could not prove his testimony about censorship, because it was not usual to issue such confirmations in Vienna, as was also shown by an attached declaration from a Vienna bookseller Christoph Peter Rehm. ${ }^{47}$ On the basis of Lindauer's statement that he could not prove with a confirmation that the texts had been inspected in Vienna, the Chancellery of Hungary issued a decree that booksellers had to ask for confirmation of an inspection and add it to the package at the Hungarian customs post, so that it would not be possible to import uninspected books as well as those inspected in Vienna. ${ }^{48}$

On 29 August 1794, Jozef Hajnóczy stated that "The Kreuzzug was already found in many hands, especially it could be obtained from the late bookseller Strohmayer" ${ }^{49}$ Thus, it is clear that the pamphlet was well known in Hungary and various people were involved in its sale.

Not only Kreuzzug could be bought from Ignác Strohmayer. At this time he had bookshops in Pest, Buda and Košice. Strohmayer sent a list of books for

$45 \mathrm{MNL}-\mathrm{OL}, \mathrm{C} 60$, cs. 81, 28102, f. 191-196, cs. 84, 1239.

46 MNL - OL, C 60, cs. 84, 4542, f. 13-17.

$47 \mathrm{MNL}-\mathrm{OL}, \mathrm{C} 60$, cs. 84, 10326, f. 19-27. Distribution of the pamphlet also had to be investigated in the town and County of Timişoara: cs. 84, 21763, f. 28-30; 27080, f. 37; 29918, f. 33-36; cs. 86, 1280, f. 393-396, cs. 86, 4148, f. 485.

48 MNL-OL, C 60, cs. 208, 21571, f. 261-262.

49 BENDA, Kálmán. A magyar jakobinusok iratai. II. kt. Budapest: Akadémiai kiadó, 1952, s. 106; KOWALSKÁ - KANTEK, ref. 7, s. 183. 
inspection by the censor Schafrath in summer 1792. Schafrath submitted the list to Riethaller. Then Strohmayer allegedly sent his servant to Riethaller to urge the granting of authorization. When they informed him that he had to wait two days, he asked for the list back with the justification that he could not print it. The censor managed to mark the forbidden books and asked the Pest city authorities to confiscate them. It turned out that meanwhile Strohmayer had sent them to Košice. On urging from the censor, he agreed to send them back at the next opportunity, which would be the Pest market. Strohmayer also claimed that he had already removed the banned books from all his bookshops, and to the question of how the books got into the kingdom, he replied that all were shown to the censor and he did not know and had no reason to use "secret ways". ${ }^{0}$

About a year later the Košice local censor Móric Sahlhausen inspected Strohmayer's bookshop in Košice. He made lists of banned and suspect books, and those he thought contained the "gallicae revolutionis principia". The town authorities had to question Strohmayer with the aim of finding out how these books got into the kingdom. ${ }^{51}$ This was the usual scenario - discovery, list, report and demanding a statement from the bookseller, who usually defended himself with claims that a censor saw the books or they were not banned at the time they were imported. It was only partly true. When searching for current political pamphlets, censors also labelled as banned books published in the 1780s or even earlier, which had not attracted any attention before 1790. They were allowed without any limitation or had the level of permission toleratur. This also applied to Strohmayer's bookshops. Not only did a bookseller move books between branches with the aim of avoiding problems, there was also change in the point of view of the censor and the relative meanings of harmful, harmless, forbidden, allowed in relation to the existing socio-political climate.

Visits by censors to bookshops and reading rooms brought results not only in the form of lists of banned books. They show us at least part of the defence of the booksellers against the pressure for control. In autumn 1793 the censor Hadaly undertook such inspections and probably unannounced visits, after which he wrote a detailed report. The booksellers allegedly showed lists of offers very hesitantly with the justification that they could not do anything because they were always receiving new publications and had "to mix up the whole shop". The bookseller Johann Doll provided no list and made various excuses to delay sending it. In the bookshop of the printer Šimon Peter Weber he found the banned

50 MNL - OL, C 60, cs. 81, 15322, f. 42-46; 24782, f. 48, 25524, f. 50-55. The list of banned and suspect books included mainly works by Karl Friedrich Bahrdt, Johann Jacob Hess and others.

51 MNL - OL, C 60, cs. 82, 29931, f. 539-544. 
work printed by Weber Babuk, oder Der Volks-Verleunder by Michal Piringer, and another banned and searched for work Grosse Wahrheiten und Beweise. He found a total of 272 banned books. This was a very large number in comparison with the results of other searches.

Hadaly also reported that in April he had found 27 copies of the Dissertatio statistica de nationali Hungarorum industria. He also found in Mahler's premises the banned brochure Intoleranz des katholischen Klerus attributed to Johann Molnár or Jozef Hajnóczy. Löwe informed Hadaly that he had received it from the Buda printer Landerer or the Pest bookseller Lindauer. Mahler had allegedly acquired it from the Lindauer.

Hadaly also visited the reading rooms, where he also asked for lists. Weissenthall allegedly attempted "to free the reading room from suspicious books by all methods". This probably commented on the fact that the inspection brought no results. The report also added that the reading room was inspected repeatedly, and the confiscated books had to be returned to the owners because they were allowed in translations. Hadaly's report provoked further investigations. The Bratislava city authorities had to question Mahler on the subject of the distribution of copies of Intoleranz..$^{52}$ Since Mahler's and Löwe's information about the source pointed to Landerer's printing business in Buda, its boss Michal Landerer had to testify about whether he printed the brochure and who inspected it. The Buda city authorities found out nothing. Michal Landerer, boss of the printing business when the brochure was printed, was allegedly in Bratislava. The current boss of the printing business Ján Tomencsek allegedly knew nothing about the matter. ${ }^{53}$ Naturally, the governor's office was not satisfied with such testimony, and it ordered the Bratislava city authorities to obtain testimony from Michal Landerer. The Bratislava city authorities reported the confiscation of 62 unbound copies found in Mahler's possession and its obtained testimony from Landerer, who stated that he had obtained 300 free copies from an unknown person. In May 1792, at the time of the coronation of Francis, he had allegedly sold 200 of them for 45 kreuzers in Buda and Pest, he sent 50 copies to Löwe and the same number to Mahler. However, the city authorities stated that the testimony about a gift from an unknown person was untrustworthy, because the reported numbers

52 [PIRINGER, Michael]. Babuk, oder Volks-Verleumder in den angeblichen grossen Wahrheiten und Beweisen... Pressburg: Weber, 1792; [BENČÍK, Jozef]. Dissertatio statistica de industria nationali Hungarorum. Viennae: [s. t.], 1792; [MOLNÁR, Johann]. Intoleranz des katholischen Klerus gegen die ungarischen Protestanten ... Gedruckt im protestantischen Deutschlande. [Pest]: [Landerer], 1792; VIZKELETY-ECSEDY, ref. 16, p. 154; MNL - OL, C 60, cs. 82, 25109, f. 356-360. 
did not agree with the numbers found in the possession of Löwe and Mahler, namely 56 and 80 copies. $^{54}$

Other traces led to Lindauer. During the investigation, he strove to convince the Pest city authorities that he had no copies. He had 150 copies, which he had allegedly bought at the time of the last parliament from an unknown trader. He did not find out who this was or his name. He sold some of the copies to Mahler, Doll, Schwaiger, Löwe and others. He knew nothing about censorship of the text. $^{55}$

How was it really? Intoleranz is a perfect example of complete concealment of authorship, publication and distribution. It appeared with two false imprints: "In protestantischen Deutschlande" and "im Stein am Anger ... mit bischöflichen Lettern". However, according to Judit Vizkelety-Ecsedy both versions originated in Landerer's printing business in Pest. The investigation proved only that the banned brochure was sold in almost all bookshops. Landerer's and Lindauer's declarations about being given it or buying it from unknown persons indicate that the booksellers did not consider the investigation to be a major complication and probably did not even think of telling the truth.

We learn something about the method of hiding a problematic import from another suspicion that fell on the bookseller Mahler. In the framework of inspecting reading rooms, the Bratislava censor Mathias Riethaller found the banned drama Van der Noot, which told the story of the uprising against Joseph II in 1789 in Belgium. Its main hero Hendrik Karl Nicolaas van der Noot (1731 or 1750-1827) was a fighter against the Josephine reforms. It is not necessary to underline that any mention of struggle, unrest or uprising was unwelcome in this period. The book was found in Johann Gleixner's reading room in Pest. Gleixner stated that he had obtained the book from Mahler, who said that he had brought the book from the Leipzig book fair before it was included in the catalogue of banned books, so that it had passed its inspection without problems. Later he sent it to Gleixner in Pest with other books. ${ }^{56}$ The Bratislava local censor Karol Hadaly had to express his view of Mahler's statement, because according to the rules, such a book was clearly suspect. He was supposed to retain it, write a report, send it to his superior and wait for instructions. Karol Hadaly explained in a letter to the study director that he had never received Van der Noot or other books from Mahler for inspection. As if attempting to avoid accusations of inconsistence or inadequate method, he explained that in the preceding years he had censored various books that Mahler had brought from Leipzig. Their titles already said everything, but he had no reason to retain such a title as Van der

54 MNL-OL, C 60, cs. 82, 30207, f. 547-548; 27473, f. 432-434, cs. 86, 3232, f. 454.

55 MNL-OL, C 60, cs. 86, 768, f. 530; 6789, f. 532-533

$56 \mathrm{MNL}-\mathrm{OL}, \mathrm{C} 60$, cs. 79, 5957, f. 359-360. 
Noot. He also pointed to the lack of consistence of Mahler's declarations. Mahler had allegedly declared to the city authorities that he brought the books from the Leipzig Easter Fair. The Buda inspector found them in Gleixner's reading room in June, but according to Hadaly's inspection diary he sent the books on 1 July. This statement was confirmed by the customs post. Mahler suffered a moderate penalty - the city authorities had to reprimand him and warn him against any further distribution of banned books. However, this case also shows us that the booksellers deliberately deceived the officials in their declarations. ${ }^{57}$

Obviously, we cannot exclude it, but so far nothing supports the view that the censors were also involved in the system of secret circulation of books in some way. The above mentioned example shows that books could be retained by the inspectors for several months. Books brought from the Easter Fair were released by the inspectors only on 1 July. The period from retaining a book to writing a report could give the booksellers or owners space to "negotiate" with the censor or other responsible persons.

In autumn 1795, the Chancellery of Hungary ordered an investigation of how it was possible that the books imported by the Bratislava bookseller Andreas Schwaiger from Leipzig included Thomas Paine's banned The Age of Reason, in German translation Gesunder Menschenverstand. The book was probably retained and censored in Vienna. The governor's office asked Schwaiger for his position $^{58}$ and he explained that it was only a misunderstanding by his correspondent, which had exchanged packages or the addresses on them. The book was supposed to go to a certain professor in Regensburg. To confirm his declaration he added a letter from the above mentioned commissioner Jacobäer explaining that Schwaiger's package had gone to Regensburg and asking for it to be sent back and everything put right. The letter also shows that the confiscated Berlinische Monathschrift had accompanied Paine's book through the Doll's bookshop in Vienna. ${ }^{59}$

It is questionable whether the packages were really exchanged or it was an attempt by Schwaiger to defend himself against the accusation that he had imported such a problematic book as Paine's revolutionary, political - philosophical work, banned in 1794. This was not Schwaiger's first problem with censorship, so according to the valid decree he was threatened with loss of his licence to run a bookshop. Schwaiger had good reason to invent a story about the exchange of packages and prove it with a letter, which the commissioner could send as a supplement on request.

57 MNL-OL, C 60, cs. 79, 8229, f. 367-371.

58 MNL-OL, C 60, cs. 89, 20480, f. 283-290.

59 MNL-OL, C 60, cs. 89, 24022, 318-320, 336; 27006, f. 352-353. 
The fact that in spite of many measures, a significant number of subversive books and brochures circulated in society is described in a letter from the Dean of the Philosophy Faculty of Buda University Ludwig Mitterpacher to the governor's office. According to him Johann Laczkovics had ridiculed and expressed indecent views on the Christian mysteries in the book A keresztény valásban magát oktatatni ember. Mitterpacher asked the questions: how had such a book got to Pest? how had it come to be publicly accessible in public markets and reading rooms? He requested measures against the "secret importing" of books into Hungary. ${ }^{60}$

Cardinal Joseph Batthány also pointed to the distribution of this brochure. The two reports provoked an investigation, but with no results. Mitterpacher's idea that it was an import was incorrect. The brochure with the imprint "Jerusalemben" was probably printed by Landerer's printing business in Pest. When the directors of several printing businesses were questioned on the matter, the director or Landerer's printing business in Pest Gabriel Rácz stated that he did not know where the book was printed. ${ }^{61}$

\section{Post wagons, elite customers, students and mediators}

The soldier, adventurer and radical Enlightenment intellectual Baron Friedrich von Trenck entered the history of Hungary especially thanks to a series of pamphlets published in 1790-1791. He published them without imprints and in more or less illegal circumstances, without authorization. He not only provoked a commotion, but also internment and eventually deportation from the country. In April 1792 he came to Hamburg, where he continued his public writing activities. He began to publish a political monthly: the Monathschrift.

The Monathschrift contained a mixture of Trenck's earlier and newer texts, political, literary and poetic. There were many articles concerning Hungary and its internal politics. He published the Monathschrift with the aim of getting it into Hungary, but it was probably distributed in other regions as well. The last issue mentions the persecution and banning of the magazine. Although its first issues were conceived in a restrained way, they were banned in Vienna. Trenck took advantage of the fact that the censorship in Hamburg was more moderate in other German territories. However, as a result of this, radical Enlightenment intellectuals interested in Jacobin ideas concentrated there. However, Trenck's radicalization after the outbreak of the revolution did not remain unnoticed, although he distanced himself from the Jacobins. The Monathschrift was banned.

60 [LACZKOVICS, Johann]. A' keresztény vallásban magát oktattatni vágyódó utazó ember. (Educating oneself in the Christian journey). Jerusalemben [Pest]: [Landerer], [1791]; VIZKELETY-ECSEDY, ref. 16, p. 150; MNL - OL, C 60, cs. 82, 15490.

$61 \mathrm{MNL}-\mathrm{OL}, \mathrm{C} 60$, cs. 78, 18964, f. 262-273. 
Its publication ended and from 1793 it was replaced by the Proserpina with the false imprint "Mainz und Altona". However, in reality it was published by the Hamburg printer Johann Peter Treder as the authorities soon discovered. Only two issues appeared. In spring 1793 Trenck went to Paris. ${ }^{62}$

The records of the Hungarian authorities explain his indefinite references to problems with censorship. In September 1792 the censor at a customs post Mathias Riethaller found a package containing two smaller parcels one intended for the Deputy Sheriff of the County of Gemer Štefan Mariássy and the other for Michal Landerer. Both contained the first four issues of the Monathschrift. The parcel addressed to Landerer also contained Trenck's Gedicht bey der Uebersicht seines Schicksals, a poetic account of experiences in Hungary in a satirical tone. ${ }^{63}$ The censor considered the content of the package offensive and he asked for the view of the governor's office. Some time later Riethaller found another package with two parcels. They again contained the Monathschrift, this time addressed to the Deputy Sheriff of the County of Pest Georg Laczkovics. The second was addressed to Landerer. At the beginning of October, Riethaller found a third similar package with one parcel addressed to Deputy Sheriff Laczkovics and the other to Landerer. They contained the fifth and sixth issues of the monthly. The governor's office decided that Laczkovics could receive his parcel on the basis of the decree about importing of banned books by educated and discrete persons, but Landerer's parcel had to be confiscated. The Vienna Court Office was informed of the finds and of some related facts: Each parcel contained multiple copies of each work, suggesting that they were not intended only for private use, but also for distribution to other people. The texts had not been properly censored so far. Some packages came from Vienna to Buda packed and with seals from the Vienna customs post removed. This authorization document speaks of four rather than three packages. The suspicion arises that Landerer's associate in Vienna manipulated the packages in some way during the journey from Vienna to Buda. Although we do not have enough information today to make things clear, what happened was enough to provoke an extensive investigation into everybody involved.

The investigation showed that although the packages were intended for various people, the customs approval was produced for Landerer, who secured the

62 KOLLÁROVÁ, Ivona. Vydavatel'ské aktivity Friedricha von Trenck v podmienkach uhorskej cenzúry. (The publishing activities of Friedrich von Trenck in the conditions of Hungarian censorship). In Studia Bibliographica Posoniensia 2015. Bratislava: Univerzitná knižnica, 2015, p. 95-102. ISBN 9788089303472; GRAB, Walter. Friedrich von der Trenck. Hochstapler und Freiheitsmärtyrer und andere Studien zur Revolutions- und Literaturgeschichte. Kronberg im Taunus: Scriptor, 1977, p. 41-52; Monathschrift, 12. Heft, p. 1131.

63 TRENCK, Friedrich. Gedicht bey der Uebersicht seines Schicksals, ... Altona : [s. 1.], 1792. 
imports for all the others. The packages were imported from Vienna to Buda, where they were taken from the post wagon, handed over to the customs post and post-marked. The correctness or falsity (correctio) of the approval and damage to the seal (probably obtained in Vienna) was also registered at this customs post. It appeared therefore that this was done by Landerer's commissioner, who also hid the fourth package covered by the customs approval. In spite of the investigation, they did not prove the most important thing, namely who manipulated the package, who arranged for the approval to be produced in Landerer's name, and what Landerer actually did concerning this matter. After several weeks of urging, Landerer sent a long letter to the Buda city authorities to answer questions connected with the case. He stated that deputy sheriffs and persons holding public functions have the legal possibility to read anything, so he authorized his representative to perform this service for them by a legal route - with the mediation of the Royal Mail and customs posts. Landerer rejected all accusations of illegal activity and attacked the censor. Riethaller had taken the packages from the post at the customs post without his knowledge and against the valid instructions so that they could be confiscated. In this way he had violated Landerer's rights. Only the censor could reply to the question of whether he had found letters or any authorization among the packages. If he had found them only he knew who they was addressed to, and why he had not submitted them to the governor's office together with the packages. Finally, he emphasized that his activities contributed to the prosperity of the city, the suspicions were unfounded, accusations were unjust and the censor was neglecting his duties.

Since there was nothing substantial in Landerer's statement, the governor's office proposed a further investigation directed towards the post wagon. It was especially necessary to find out the circumstances of transport of the packages through Vienna.

When Trenck began to publish the monthly Proserpina in January 1793 instead of the Monathschrift, the court office of Hungary immediately banned it.

The Leipzig bookseller Gräff secretly imported Trenck's works into Hungary and sold them for 6 gulden a copy. All the inspectors had to take care that books did not get into Hungary on post wagons or in other ways. It was also necessary to watch the routes from Moravia and imports from France. The chairman of the Hungarian Chamber and post wagons also had responsibilities. The price of 6 gulden indicates that Trenck was not exaggerating when he said that he was a popular author and his publications were sold for a profit. We can also admit that rumours about his person and the banning of his works made them sought after and raised their price. In July Riethaller reported to the governor's office that he had no indications that further importing was happening either in post wagons or 
by other routes. The local censor of Buda Leopold Schafrath sent a similar report to the governor's office. The study director in Košice expressed a similar view.

However, the records of local censors show that his books were being offered by booksellers in spite of the prohibitions. ${ }^{64}$

In his autobiography, Trenck mentions friendship with Joseph II and Leopold II and with members of the elite of Hungary. His correspondence with the Jacobin Johann Laczkovics (1754-1795) is also proveable. Der macedonische Held was translated into Hungarian. In autumn 1791 Laczkovics probably helped Trenck with gaining freedom and with gaining a pension. The packages of books show his contacts with the Pest deputy sheriff Georg Laczkovics and Jozef Szily and with the deputy sheriff of the County of Gemer Štefan Mariássy, ${ }^{65}$ although during the investigations they only admitted to a slight acquaintance, associated with Trenck's activity sending his publications. Members of Landerer's clan operating at the time in Pest, Bratislava and Košice also did not report knowing him, although their activities in publishing and distributing his texts were extensive.

We can admit that Trenck also built up private contacts with highly placed people in Hungary so that he could use them as mediators for selling his texts. He never hid the fact that writing was his profession because his pension was not enough to support his large family. Although he used mainly private journeys to distribute his texts, contacts with printers clearly played a key role. They printed his works in spite of the danger of problems. The investigation and the sending of various copies of one work or issues of a magazine opens the question of the role of the deputy sheriffs in the distribution of texts in their surroundings. We have to admit that something more than friendship led to Trenck's effort to use the degree of immunity of highly placed people where the receipt and distribution of a problematic magazine was concerned. ${ }^{66}$

Michal Landerer printed two volumes of his collected works and probably also other texts in his Buda printing business but with false imprints. In connection with this, it is necessary to mention that after the discovery of Martinovics's conspiracy, he was condemned as a Jacobin to execution with a sword and confiscation of property. The punishment was later reduced to imprisonment.

64 KOLLÁROVÁ, ref. 62, p. 96-100.

65 ZSIGMOND, Gyula. Önéletrajz. (Autobiography). In Trenck Frigyes báró. Emlékezetes élettörténete. Budapest: Európa, 1989, p. 377. ISBN 9630749920; BENDA, ref. 49, p. 98; GRAB, ref. 62, p. 31.

66 On the role of the nobility using political immunity in illegal distribution: HAUG, Christine. Topographie des literarischen Untergrunds im Europa des 18. Jahrhunderts: Produktion, Distribution und Konsumption von ,verbotenen Lesestoffen“. In HAUG, Christine - MAYER, Franziska - SCHRÖDER, Winfried (eds.). Geheimliteratur und Geheimbuchhandel in Europa im 18. Jahrhundert. Wiesbaden: Harrassowitz, 2011, p. 24. ISBN 9783447064781. 
In 1806 a Kremnica advocate reported to the governor's council that he had found private letters inserted in "Landerer's newspapers". These could be nothing other than the Pressburger Zeitung mentioned in the introduction, which was published by Landerer for several decades. We know no other facts about these packages. The letters were handed over to the post office and Landerer had to testify to the city authorities why he had used this illegal method to send letters. ${ }^{67}$

This suggests something we cannot clearly prove. It places us before a question or perhaps a hypothesis that while the post was used to send illegal packages of periodicals, it was also possible during the period of the Napoleonic Wars and strict controls on packages, for censored and approved copies of newspapers to serve as a means of smuggling other problematic content. Only further research could confirm or deny this hypothesis.

Even in the 1780 s the name of a highly placed person indicated the inviolability of problematic imported books. According to a decree from 24 February 1783, noble and educated people were allowed to import banned books. Trenck's case and the new decrees show that this did not necessarily apply in the 1790s. When the Frankfurt bookseller Friedrich David Esslinger sent some French books to Count Mikuláš Forgác (Forgach), the Bratislava censor detained them and confiscated one as forbidden. Forgáč declared in his letter requesting its return that he was an educated and decent subject, the books were intended for his collection and his ownership of them should be understood mainly as an interest in literature and not as a preference for inappropriate ideas. ${ }^{68}$

In November 1795 Karol Hadaly retained a package from the Viennese bookseller Joseph Stahel. It was intended for the Banská Štiavnica mining trainee Count Pálffy. It contained three issues of the historical and political magazine Minerva from July, August and September 1795. The censor considered the magazine suspect and wanted to return it only if it did not appear in the updated index. The package also contained the banned book Kurze Geschichte der ewangelisch-lutheranischen Kirche in Ungarn with an approval for the Štiavnica senator Paul Sietzenthaler issued by the Vienna court inspector Karol Escherics with the knowledge of the chancellery of Hungary. In spite of this, Hadaly confiscated the book on the ground that it was banned in Hungary. In his view, obtaining books in Vienna rather than Buda, with the aim of evading censorship, not only evaded the effects of the current decrees, it also took away the profit

67 Archív mesta Bratislava, Decrees of the governor's council, F 4 no. 77, 450. 6 April 1806.

68 MNL - OL, C 60, cs. 81, 22613, 166-167. The banned book: LAVICOMTERIE DE SAINTSAMSON, Louis. Les crimes des rois de France, depuis Clovis jusqu'à Louis XVI. Paris: bureau des „Révolutions de Paris“, 1792. 
of Hungarian booksellers. Therefore, the acquirers had to apply for permission from the governor's office. ${ }^{69}$

These cases bring to the fore not only elite customers, but also the fact that instead of a simple importer - customer arrangement, the system was complicated by further elements that are almost entirely absent from the records of earlier periods. They include students and various mediators of the problematic imports.

In 1797 the governor's office ordered superintendents to inspect student residences, take away inappropriate books and investigate the sources from which they had been acquired. The stated reason was that: "Young students often secretly obtain banned books and read them." This eliminates the effects of a good upbringing and education..$^{70}$ The reason was probably not only unprovable, the history of the typographic medium is accompanied by the metaphor of poison flowing from the reading of harmful books, but specific stimuli.

A certain student named Banyás from Banská Bystrica returned from abroad in November 1794 and wanted to import some books including Schiller's Kleinere prosaische Schriften and the second edition of the book Über die heimliche Sünden der Jugend by Christian Gotthilf Salzmann on the sex education of the young. Both books were banned. In the same report the study director informs the governor's office that the books of another theology student Francis Borza from the lordship of Néma (today's Klížska Nemá) in the County of Komárno, who had returned from Saxony, included Immanuel Kant's work Die Religion innerhalb der Grenzen der blossen Vernunft and Campe's Schleswigesches (formerly Braunschweigisches) Journal from 1792. The student declared that the Vienna censor had approved the books. However, Fleischacker replied that the books were banned and so needed authorization if they were imported. ${ }^{71}$

In June 1795 the Bratislava censor found and confiscated a package of books belonging to the candidate of theology Georg Barth, who was returning through Vienna to the village of Ács, where he had to take up spiritual office. They included the eighth part of the Collection of interesting and comprehensive travel writings for young people. The author Joachim Heinrich Campe was an enthu-

69 [TEKUŠ, Ján Michal]. Kurze Geschichte der ewangelisch-lutherischen Kirche in Ungarn. Göttingen: Vandenhoek - Ruprecht, 1794. MNL - OL, C 60, cs. 90, 26014, f. 421-424. The bookseller Mahler also wanted to import the book: cs. 90, 6343, f. 276. This report again mentions the bookseller Stahel (the censor intercepted the book by Peter Villaum Über das Verhältniss der Religion zur Moral, sent by the Bratislava trader Sloboda to a certain Samuel Steinhübel, wine merchant in Prešov. The report documents finds of obscene books and pictures in the possession of Mahler and in Bratislava markets.

70 From the decree of the governor's office to the superintendent of the Cis-Danubian District, 14 Nov 1797. The Central Library of the SAS, Collection of the Grammar School in Banská Bystrica, BB 395, B. Intimata Regia ab anno 1792, p. 2.

71 MNL-OL, C 60, cs. 89, 25782, f. 343-345. 
siastic supporter of revolution and this was reflected in his "travel writings for young people". The censors could not fail to notice this and the work was banned in February 1793. ${ }^{72}$ Barth stated that he had bought the book in Vienna from the "bookseller Sommerer" (actually Rudolf Sammer the elder) and it was censored there.

The same statement contains the information that the censor had found and confiscated two copies of the book Zwölf Sibyllen Weissagungen among the books of a certain Steinlechner, a student at the Bratislava general seminary. The student stated that the Vienna bookseller Johann Georg Binz had sent them to him, and their titles were included in his approved catalogue of books published in the Wiener Zeitung. Thirdly, the censor retained three boxes from the Viennese traders Johann Konrad Hippenmaier (Hyppenmaier) and Brüxner intended for the Pest shopkeeper Johann Samuel Liedemann. The packages had authorizations produced in Vienna. The censor found that banned books had been added to permitted ones. The seventh and eighth parts of Campe's above mentioned travel writings were found as well as several issues of the review periodical Neues Theologisches Journal from $1794 .^{73}$

This information became the stimulus for a thorough investigation not only in Bratislava but also in Vienna. All the relevant tradesmen were questioned, and records of payments made it clear that another Bratislava commercial enterprise - Jung's heirs and Klement - and several more mediators were involved in these transactions. Hyppenmaier, a wholesaler on the Haarmarkt, testified that he and his associate had not traded in books, but when they had received these books from friends, so that they could mediate their transport, they had them regularly inspected, paid fees and sent them to people according to instructions from the senders. They did not know themselves what was in the packages. The Vienna inspection office did not inspect the books but sent them to their intended destination, namely Bratislava. However, they entirely distanced themselves from the package intended for the Pest tradesman Liedemann. They claimed to have no mention of him in their dispatch books and other records. The only

72 CAMPE, Joachim Heinrich. Sammlung interessanter und durchgängig zweckmässig abgefasster Reise-beschreibungen für die Jugend. Braunschweig. 1786-1790. Various publishers. MNL-OL, C 60, cs. 82, 4217, f. 62. 7 February 1793: Office of the Governor of Hungary: ad Classem prohibitorum relata.

73 Sibyllen Weissagungen dated from the $16^{\text {th }}$ century but with various changes. The Augsburg edition of 1750 was banned in the Habsburg Monarchy. Another edition found in catalogues but without publication data, originated about 1790. MNL - OL, C 60, cs. 89, 12625, f. 187-189. Fleischacker's report designates Hyppenmaier and Brüxner "librorum quaestores" like Binz. A list of Viennese booksellers does not include their names. FRANK, Peter FRIMMEL, Johannes. Buchwesen in Wien 1750-1850. Kommentiertes Verzeichnis der Buchdrucker, Buchhändler und Verleger. Wiesbaden: Harrassowitz, 2008. ISBN 9783447056595. 
package that could be proved on the basis of their documentation was a box of books that came on 27 March 1794 from Abraham Matthias Levi of Fürth. Levi only mediated the sending of the package for Filip Gause of Regensburg. It was intended for the Bratislava trading firm Jung heirs and Klement. It was inspected only in Bratislava, so they could not know what it contained. He thought that somebody else had sent it under his name. This should be provable at the customs post, which should have a customs declaration, one of which went with the goods while the other remained at the customs post. If this was verified it would show whether Liedemann was deceiving them. A statement from the Bratislava censor shows that the package was brought by boat from Vienna to Bratislava, and eventually reached Liedemann in Pest with the mediation of the firm of Jung heirs and Klement. The banned books were found in the box among other Hebrew books. They did not have the stamp of the Vienna censors office, only of the Vienna customs post. Liedemann distanced himself from the package in his statement. He claimed that he did not remember getting any books from Hippenmayer and Brüxner, only some calendars. Campe and the Theologisches Journal banned books were allegedly his property. All the books in which he traded were submitted for censorship and had been for 10 years. He did not remember this specific case. The names were probably changed at the customs post, something that allegedly happened very frequently.

The bookseller Johann Georg Binz stated that he had 30 copies of Sibyllen Weissagungen sent from Nuremberg. They were inspected at the inspection office and advertised about 20-30 times. He also claimed that two copies were ordered by Steinlechner of the Bratislava seminary, but the latter denied it. Binz allegedly did not sell the book after he knew it was banned.

The bookseller Rudolf Sammer stated that he had 6 or 8 copies of Campe's book brought from Reutlingen about three years before. He obtained approval from the censor Hoffinger. He had not sold any since the book was banned, and did not remember selling one to a theologian named Juraj Barth.

The investigation led only to a ban on any bookseller publishing advertisements that had not been inspected. In the web of transactions, contradictory statements and pieces of evidence, the only thing consistently proved was that problematic books were reaching the stocks of bookshops and books were getting banned only after they had entered the country without any restriction. This helped to provide sellers with alibis or to create smoke screens. The remarkable number of intermediaries from Germany, Vienna, Pest and Bratislava associated with one package, in which problematic titles were inconspicuously mixed with unproblematic, also contributed to this. ${ }^{74}$

$74 \mathrm{MNL}$ - OL, C 60 , cs. 89, 26386 f. 1-26. A further investigation had to be directed mainly towards Brüxner and Hippenmaier. The Pest tradesmen Liedemann had to be questioned and 
A further circumstance complicates the unclear situation. In summer 1795 another student - Samuel Csáky from Transylvania - asked for the return of a confiscated package containing Campe's travel writings and the Neues theologisches Journal with the argument that the books were only for his own use and a friend had sent them to him. At first sight this turns us to the previous case, but this name did not appear in the investigation. Therefore, we can recognize that another imported package is involved and it may or may not have any connection with the previous case. Csáky asked for the return of the same volumes of Campe's travel writings and the same issues of the periodical as those involved in the above mentioned case. As in the preceding case, the problematic books were probably deliberately mixed with unproblematic titles so that the censor would not notice them at first sight. The books were probably found at the frontier crossing together with others. The censor also retained the banned rationalist work by Eucharisius Ferdinand Christian Oertel Versuch einer philosophischen Bibelerklärung and Kant's Die Religion innerhalb der ganzen der blossen Vernunft and the Neues Magazin für Prediger published by the Enlightenment Evangelical theologian Wilhelm Abraham Teller (1734-1750), a representative of rationalism, naturalism or deist naturalism. Other books with the degree of approval erga schaedam were also retained. ${ }^{75}$

\section{Testimony from a parallel world}

"However, [Amry] almost treated me badly, when he did not mention anything in the customs declaration from my trunk with the double bottom where the books were found... If my good friend had not carried out the search, the whole package would have been regarded as smuggled goods. ${ }^{776}$

the circumstances of obtaining customs confirmations in Vienna. Although Liedemann is described as "bibliopola" here, he did not specialize in sale of books, but was a general trader and transporter of goods. A document from the Bratislava customs post shows that a package was sent to Prešov. MNL - OL, C 60, cs. 91, 4879, f. 71-74. Liedemann's testimony: cs. 91, 2898, f. 668-669.

75 MNL - OL, C 60, cs. 90, 25468, f. 389-397. The package was not handed over because the request was repeated in the autumn: MNL - OL, C 60, cs. 90, 19935, f. 386-388, 22231, f. 398-400. Another investigation of Campe's travel writings occurred in Pest in May - June 1795: cs. 89, 11955, f. 181-185. Traces led to Lindauer, who stated that he had imported the book from Leipzig before it was banned and before the existing regulations applied. He sold it to the Debrecen bookseller Stephen Fodor, acting as a distributor (bibliopega) for the Bratislava printer Ján Michal Landerer: cs. 83, 23831, f. 173-176, 29907, f. 200.

76 From a letter from the Viennese tradesman Christian Heinrich Coith to the Halle bookseller Gebauer. 15 October 1777. BULKOVÁ, Petronela. Komunikačné siete v poslednej tretine 18. storočia. Korešpondencia Johanna Scholtza a Johanna Jacoba Gebauera. (Communication networks in the last third of the $18^{\text {th }}$ century. The correspondence of Johann Scholtz and Johann Jacob Gebauer.). In Studia Bibliographica Posoniensia 2014. Bratislava: Univerzitná 
Declaration, investigation and confiscation are the tip of the iceberg of the invisible world of the secret book trade. The information that "emerged" thanks to the observance of the monitoring system is the basis for consideration of what the monitoring authorities did not find out.

The complicated socio-political climate in the period of the Great French Revolution nourished the vision of the secret printing cell oriented towards the production of political, Jacobin inclined texts. However, one was never successfully uncovered and the investigations did not lead to any indications, although anonymous accusations were frequent in this period and supported by promised rewards anchored in decrees. The large number of anonymous texts with concealed publication data so that the authors and producers were usually not discovered in spite of efforts to do so, probably led to suspicions about the existence of illegal typography.

There was increasing pressure on booksellers and private people who imported books. Did it influence their behaviour? Preventive measures concerning imports were not new, but in the 1790s certain facts or statements from booksellers were repeated in the framework of investigations. We can abstract from them various tactics and methods of excusing or refuting suspicions of illegal imports:

- The bookseller stated that he did not have a banned book in stock, does not have it, knows nothing about it (later proved untrue) and does not remember it.

- Untrue statements about the number of copies in the shop.

- The bookseller cannot say because he is allegedly away on a journey.

- He cannot say because at the relevant time he was away from the shop and an assistant who no longer works there was responsible.

- He had the book censored in Vienna, but cannot prove it.

- He imported the book, usually from Leipzig, before it was banned.

- Packages were exchanged. The problematic package was intended for somebody else, perhaps a "Bavarian professor".

- Moving books between branches or bookshops.

- Manipulation of packages in post wagons.

- Packaging banned or problematic publications with other unproblematic books.

- A large number of mediators acting in unclear and unprovable ways.

- Pointing out the unjustified acts of the censor.

We rarely have the original record of an interrogation. Booksellers and printers usually sent written statements to the town authorities. Thus, they had time

knižnica, 2014, p. 148. ISBN 97880893030723. 
for preparation, consideration, consultation, influence of "their" people in the town council carrying out investigations initiated by the governor's office. The introductory quotation indicates that the importers apparently had contacts at the control points and they did not have to be only censors.

The records do not show how water transport was involved in secret transportation. Boats were used by traders and probably also booksellers, for example, to transport goods to the markets in Pest.

A micro-view into the censorship records of a certain period can show in a wider context the tradition "invisiblization" of problematic texts. This context includes manuscript publication avoiding the risks of authorization and public sale, use of inconspicuous cheap formats and the anonymity of authors or translators, concealment of the background to publication and cryptographic methods. ${ }^{77}$

Analysis of correspondence, unpublished manuscripts and other personal documents reveals private, non-public expressions and ideas. This can be seen, for example, in the thinking of parts of the intellectual elites. It shows doubts about established religious teachings, sympathy for reform of the Church, deism, reception of the modern European philosophy of Voltaire, Rousseau, Kant and others, and admiration of the Great French Revolution. ${ }^{78}$

Other personal documents such as autograph books or so-called Stammbücher show that the works of Voltaire, Rousseau, Holbach and Kant were present in communication in spite of bans. They circulated in private circles and were not subject to censorship. Quotations from recent philosophical and literary works in their individual entries show interest in modern philosophy and can be a source for research on the spread of unwanted ideas in the period after the revolution, or of world view orientations such as deism, naturalism or atheism differing from the standard and approved Christian tradition. ${ }^{79}$ Ján Kollár mentioned in his memoirs the yeoman Matej Zmeškal, who "was a so-called naturalist, that is a free-thinker. His library included anti-religious books. ... He had the majority of the works of Voltaire, Rousseau, Bayle and others". He explains how "he got to know all the atheists, naturalists, deists and God knows who else". ${ }^{80}$ The handwritten notes of the lawyer and ethnologist Ján Čaplovič show interest

77 HAUG, ref. 66, p. 22-27.

78 See, for example: TINKOVÁ, Daniela. Jakobini v sutane. Neklidní kněži, strach z revoluce a konec osvicenství na Moravé. (Jacobins in cassocks. Turbulent priests, fear of revolution and the end of the Enlightenment in Moravia). Praha: Argo, 2011. ISBN 9788025704417.

79 KOLLÁROVÁ, Ivona. Historická pamät' v pamätníkoch. (Historical memory in autograph albums). In Pamiatky a múzeá, 2015, year 23, no. 4, no. 25-26. ISSN 1335-4353.

80 KOLLÁR, Ján. Pamäti z mladšich rokov života. (Memories of youth). Bratislava: Tatran, 1997, p. 126. 
in and knowledge of political and philosophical texts mostly belonging to the "damnatur" category. ${ }^{81}$

The works of Kant and Campe are dominant in the micro-view of the censorship sources analysed in this study, but conclusions about readers' preferences cannot be formulated even preliminarily on the basis of this finding. It is only one view of the reading material of part of the political and intellectual elites. It is only part of the truth about the unwanted reading material of the wider population, which included popular novels, erotic literature and obscene pictures.

The construct of dangerous reading and metaphors about its harmful effects are a permanent feature of the history of reading. We see censorship today not only as an act of power and supervision, but also as a formative and productive part of social communication. The visible form of past reality is accompanied by the constant and inseparable latent form. The anonymity of the media environment, unclear reports about secret packages, fear of secret printing presses and private expressions of inclination to forbidden philosophies are visible effects of this latent aspect. In spite of rejection and exclusion from social consciousness, non-conformist ideas found ways to survive. ${ }^{82}$ In this space, pamphletists, professionalizing writers, printers, booksellers and their customers were constantly perfecting their immunity and adaptability in relation to attacks from the "external enemies". They were elements of a world where untolerated content spread and was reproduced in spite of bans and rejection or thanks to them.

* This study was supported by a grant from the Agency for support of research and development no. APVV-14-0644 Continuities and discontinuities of political and social elites in Slovakia in 19th and 20th centuries.

81 Literary Archive of the Slovak National Library J 4 Literarische Notaten von J. 1806 angefangen. For example, there are excerpts and notes from the banned works of Daniel Jenisch, Kant, Voltaire and others

82 KHURANA,Thomas. Latenzzeit. Unvordenkliche Nachwirkung: Anmerkung zur Zeitlichkeit der Latenz. In DIEKMANN, Stephanie - KHURANA, Thomas (eds.). Latenz. 40 Annäherungen in den Begriff. Berlin: Kadmos, 1993, p. 142-147. ISBN 9783865990398; BUTLEROVÁ, Judit: Zavrženo: jazyk cenzury. (Rejected: the language of censorship). In PAVLÍČEK, Tomáš - PÍŠA, Petr - WÖGERBAUER, Michael (eds.) Nebezpečná literatura? : Antologie z myšleni o literárni cenzuře. (Dangerous literature?: Anthologies of thought on literary censorship). Brno: Host, 2012, p. 83-102. ISBN 9788072948598. 


\title{
Geheimes Buchgeschäft nach dem Ausbruch der Großen französischen Revolution
}

Symptome der latenten Geschichte der Kommunikation

\author{
IVONA K O L L Á R O V Á
}

Die Disziplinierung und das Verbot werden heute als ein Bestandteil der Geschichte der Kommunikation betrachtet und eine Übereinstimmung herrscht auch darin, dass sie die Verbreitung des nicht tolerierten Inhaltes nicht verhindert haben, sie jedoch in einen unsichtbaren Modus einstellten. Diese Betrachtung ändert die Geschichte des Buchgeschäftes und des Lesens auf Versuche seine bisher unvollkommen gekannte, abgewandte Seite zu rekonstruieren. Die Dränge der Disziplinierung haben eine latente, den bewachenden Augen verborgene Welt erschaffen. Die Quellen bieten selten Erwähnungen und Indizien an, auf Grund deren diese enthüllt werden könnte. Teilweise ermöglichen es die, die Untersuchungen anonymer politischer Streitschriften meistens aus der Feder Österreich-Ungarischer Jakobiner festhaltenden Zensoren Akten, und auch erfolgslose ganz-Österreich-Ungarische Fahndungen nach der geheimen privaten Druckerei, welche aus der medialen Umgebung die problematischen anonymen und die „öffentliche Ruhe “ gefährdenden Texte beseitigen sollten. Die Analyse der innovierten Zensoren-Legislative nach der Ausbreitung der Revolution weist nicht nur darauf hin, wie der Import der unerwünschten Buchhändler-Ware verhindert werden konnte, jedoch implizit auch auf die Vorgehenseisen, welche die Buchhändler für diese Zwecke eingesetzt haben. Aus den Untersuchungen und den Aussagen der Buchhändler können Verallgemeinerungen über die Praxis des illegalen Imports und über die Anpassung der Importtaktik an die eingestellten Bedingungen, sowie über die Art und Weise der Ablenkung der Aufmerksamkeit und der Exkulpation bei der Zurückhaltung der verdächtigen Ware gemacht werden. Es stellt sich heraus, dass der geheime Buchhandel eine wichtige Sphäre der Geschichte der Kommunikation darstellt, in der sich nicht tolerierte Ideen trotz Gesetze verbreiten und reproduzieren.

doc. Mgr. Ivona Kollárová, PhD.

Historický ústav SAV

P. O. BOX 198, 81499 Bratislava, Klemensova 19

e-mail: Ivona.Kollarova@savba.sk 